\title{
Political Ecology in Merbeel: A Power Play around Past and Present Wetland Resource Management
}

Bhaswati Das ${ }^{+*}$ and Dr Sujit Deka ${ }^{i}$

\section{Abstract}

The interrelationship between human society and nature is multifarious. Indeed, interrelationship involves different power plays either in explicit or implicit forms. In different indigenous societies of the world, different actors have been influencing the natural resource management process. With time, the power plays commenced by such actors have been altering their forms with different actors at the zenith of hierarchical man-environment relationship. This research is an attempt to explore a succession of such power plays around a historically famous wetland Merbeel and its island of Upper Assam. The research methods followed here is qualitative. A participatory research approach is used to explore different local dynamics. The research shows that the wetland and its island have perceivably been under a through hegemonic control of different groups, from time to time. Due to natural resource availability, Merbeel and its island have always been in the epicentre of these hegemonic power plays. This study provides a brief explanation of this succession process of these power plays dividing it into three periods.

Keywords: Political Ecology; Qualitative Research; Merbeel; Assam

\footnotetext{
${ }^{+}$Research Scholar, Gauhati University, Guwahati, Assam

*Corresponding Author, Email: bhaswatidas37@gmail.com

i Professor \& Head, Department of Geography, Bodoland University, Kokrajhar - 783370, Assam, India, Email: sujitdeka@gmail.com

(C) 2020 Das \& Deka. This is an Open Access article distributed under the terms of the Creative Commons Attribution License (http://creativecommons.org/licenses/by/2.0), which permits unrestricted use, distribution, and reproduction in any medium, provided the original work is properly cited.
} 


\section{Introduction}

Political ecology provides an exploratory insight towards politics inherent in social interrelationships with nature, often with a focus on contentions and struggles over land and natural resources (Karlsson, 2015). In different parts of the world, the political dynamics interlinked with the man-environment relationship are different in nature. However, the nature of discursive struggles associated with these dynamics has some common characteristics. Such a commonality that gets reflected in every case of political ecology is the struggle for power (Svarstad, Benjaminsen and Overå, 2018). 'Power' vacillates and facilitates discursive societal relations in both production and realisation of 'truth' through the subjective articulation of reality to support the establishment of established normative order (Foucault, 2001). Power is discursive hence omnipresent but varies in forms in diverse contexts - from subtlety to domination in mutable intersections of space and time (Allen, 2003; Foucault, 2001). Although power may be perceived in both positive and negative terms; however, in the course of this research, it is mostly used in a negative and hegemonic sense. Indeed, power works intricately in vituperative correlation with ideological hinges of the normative order of the dominant class to establish a certain sense of 'hegemony' aimed at subtle consolidation of the edict of an undeniable hierarchical order.

This research is a micro-level study of such hegemonic power that plays around a wetland and its island. The finding of this research unfolds the succession process of those hegemonic power plays and transforming roles of different actors involved therein. Indeed, the correlation of the trend of transformation of hegemonic power apparatus vis-à-vis the equation of resource accessibility and sociocultural acceptability in the region is the critical factor in understanding the functioning and sustenance of power apparatus. Such microlevel analysis is of utmost importance as it reflects the socio-political interplay of different actors around natural resource and exemplifies the grass-root level marginalisation of indigenous people in their local environment.

This research begins with a brief review of the literature. In the next sections, it demonstrates three different stages of power play in and around a wetland of the study area. Following this, it discusses the past and present scenarios, keeping the analysis of power as the axis in the anatomy of the research.

\section{Literature Review}

Sullivan and Stott (2000) signify the importance of tracing the genealogy of narratives that construct the idea of the environment in society and the resultant power relationship established through those narratives which certify the hegemonic power struggle over and within that particular social system. A question arises here: 'Who decides the right or wrong in a manenvironment relationship of a particular social system?' The answer to the question is somewhere associated with Antonio Gramsci's concept of 'hegemony', which is instrumental to explicate how the structures of power configure class hierarchies for the assertions of the ruling class to legitimise their position of authority (Gramsci, 1987). One has to note here that the term hegemony was originally advocated by the Marxist, Vladimir Lenin.

Hegemony is a form of social power that relies on voluntarism and participation, rather than the threat of punishment for disobedience (Stoddart, 2007). Gramsci propounded that it is through cultural hegemony rather than violence, coercion, or economic force that the bourgeoisie maintains, produces and reproduces hegemony. In his editorial in 2017, Venkat Pulla demonstrates as to how the notion of Gramscian 'counter-hegemony' is applied by the Prime Minister, Mr Narendra Damodar Modi in his idea of building new India, where $\mathrm{Mr}$ Modi is portrayed as a 'messiah' (the saviour) of the poor (Pulla, 2017). However, a further in-depth research is required to study, whether Mr Modi can really be considered a messiah of the poor. In the current scenario, it is hard to imagine and understand contemporary political ecology 
without understanding hegemony as a central conceptual resource, and hegemony makes no sense if one does not accept that the ethnicpolitical is no mere superstructural expression but can play a pivotal role in changing the course of history (Mann, 2009). Both political ecology and hegemony are thus two intrinsically associated concepts that could enhance the analytic process of each other. Presently, in developing countries, environmental crisis has taken multifaceted forms alongside a complicated nexus of socio-economic implications. Bryant argues that poverty leads to environmental degradation, as he outlines the image of the poor as the main culprit in different environmental problems (Bryant, 1997). However, we argue that the poorest of the poor (plus people living above the poverty line), with little or no power; living in different forms of multi-dimensional poverty (Alkire et al., 2015) lead an eco-friendly lifestyle. The 2015 Paris Agreement too clearly demonstrates that climate change is contributed as a result of industrialisation, which signals that it is the developed nations, who are far more industrialised than that of the developing nations; but the brunt of climate change is borne more by the poor people of the underdeveloped and the least developed nations than the developed nations. Hence, the Paris Agreement has agreed that the countries need to adhere to global temperature rise to below 2 degree Celsius and possibly further to 1.5 degrees Celsius. As the Agreement mentions:

[The] central aim [of Paris Agreement ]is to strengthen the global response to the threat of climate change by keeping a global temperature rise this century well below 2 degrees Celsius above pre-industrial levels and to pursue efforts to limit the temperature increase even further to 1.5 degrees Celsius. Additionally, the agreement aims to strengthen the ability of countries to deal with the impacts of climate change. To reach these ambitious goals, appropriate financial flows, a new technology framework and an enhanced capacity building framework will be put in place, thus supporting action by developing countries and the most vulnerable countries, in line with their own national objectives. The Agreement also provides for enhanced transparency of action and support through a more robust transparency framework. ${ }^{1}$

Access to a decent home, food, medicine, pollution-free environment, pure water, decent work hours and adequate leisure time are fundamental rights of every individual. However, it can be rightly argued that the poor have very limited fuel to burn; women and girls walk for miles to fetch water, fuel and fodder (Dyson, 2008; 2014; Singh, 2014; Singh, 2015); they have little electricity to consume; unlike the bourgeoisie, they use feet or bicycle as a mode of communication (Bhattacharyya, 2017; Bhattacharyya and Pulla, 2019). Thus, 'the poor' ultimately get accommodated to another form of Machiavellian cycle, as participating poor. There is a limited commitment towards redistribution of power among all stakeholders involved in developmental programmes, and decision-making power is still with the government agencies (Coria and Calfucura, 2012). This study, however, examines a slightly different context. Indeed, this study is a pioneering assessment of local dynamics involved in natural resource management - from the historical period of concealed hegemony to the modern form of institutionalised hegemony. In doing so, it explores the aspect of how consensus, both tacit and explicit, is generated strategically to legitimise the institutionalisation of hegemonic power equations.

\section{Research Methods and Research Site}

This study is conducted in a rural region of Upper Assam, geographically located in NorthEastern India. The region is popularly known as Merbeel region, and it belongs to Merbil gram panchayat of Dibrugarh district. The name of the region is attributed by a famous wetland Merbeel, located in its northeastern part. The wetland has great historical significance and an

\footnotetext{
${ }^{1}$ The Paris Agreement, United Nations Climate Change. Retrieved on 09 January 2020 from, agreement/the-paris-agreement
} 
immense role in the formation of regional identity. The location of the wetland is presented in Figure 1. Merbeel wetland has an unusual ox-bow shape with an area of 1550 square kilometre. The island, situated amidst the wetland is of 350 square kilometres. It is endowed with a range of flora and fauna. The uniqueness and diversity of the wetland; Merbeel is exemplified by the presence of several species of water birds (Figure 2).

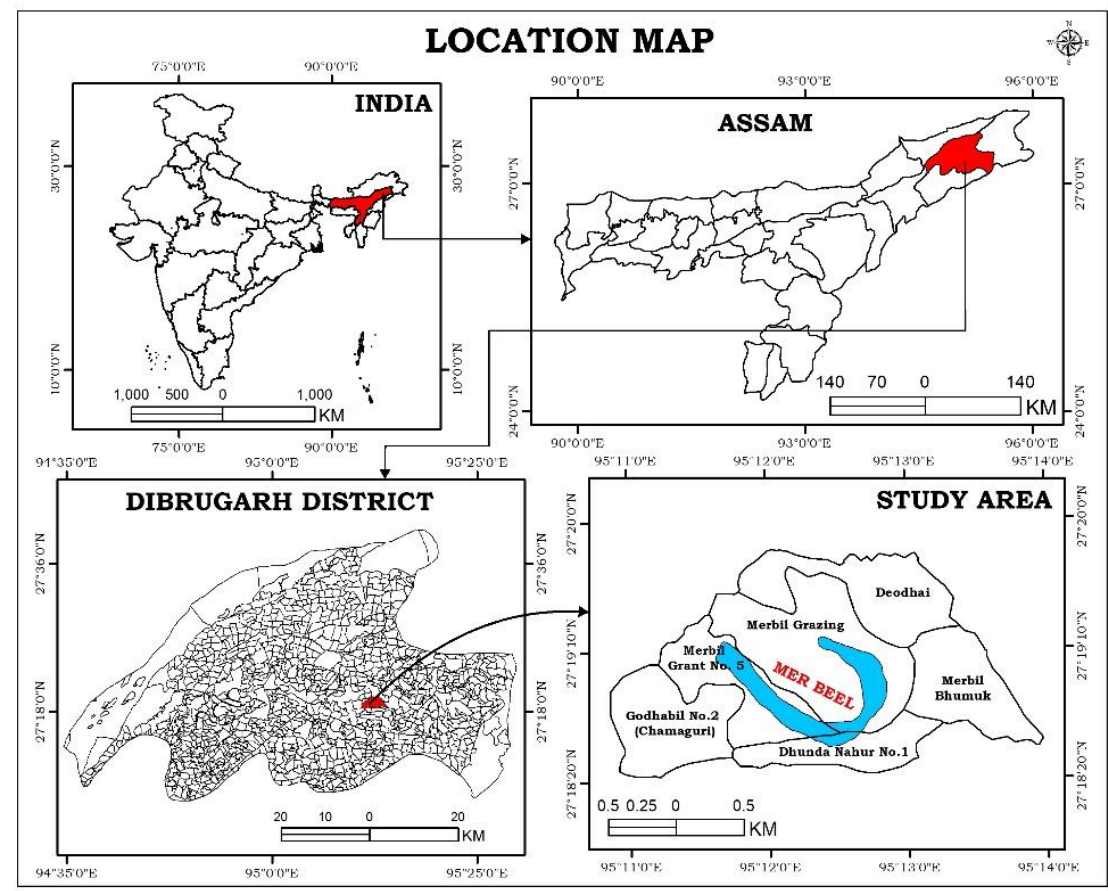

Figure 1: Location Map of the Study Area Source: Created by the Authors

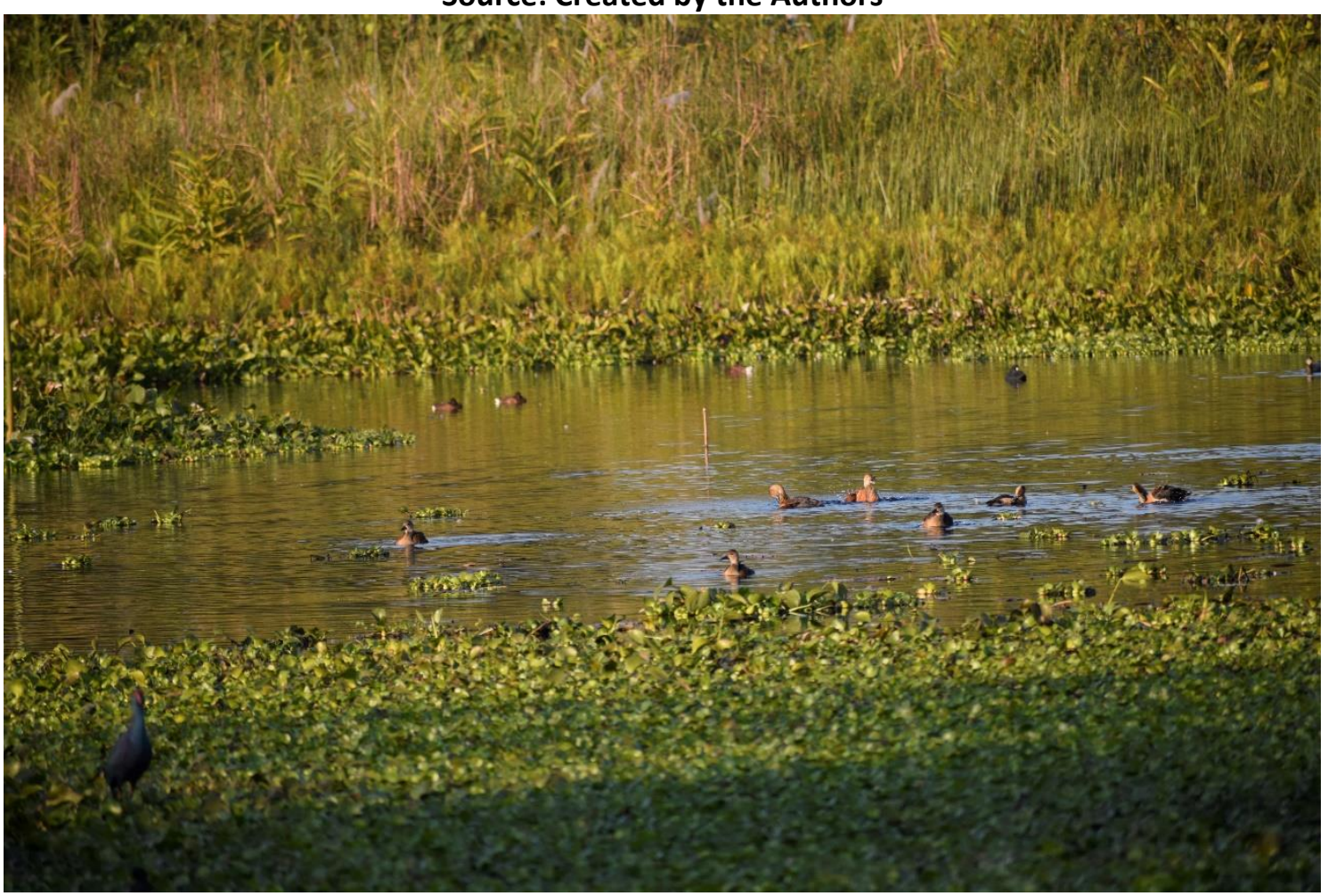

Figure 2: Water Birds at Merbeel Source: Authors 
This study is based on qualitative research methodology. This type of research is preeminent in taking account of diverse complexities of facts through the incorporation of real-world dynamics (Hancock, Ockleford and Windridge 2007). To understand the overall background of the region, the first author had stayed in a local village Hukani for two months from July 2018 to August 2018. During that period, the author conducted unstructured interviews of villagers in all the 24 villages of Merbil gram panchayat. From the key interviews, different historical dynamics related to the wetland were explored. One historical text, narrating the folklore was also collected from a key informant.

Besides, the traditional practices associated with Merbeel and its island were documented, as these practices are a very significant part of the cultural identity of the region. The finding unfolds the concealed power plays associated with natural resource management of Merbeel wetland and its island. The finding of the research is divided into three subheadings to explain three different stages of power plays in and around the wetland resource management:

- The historical period of concealed hegemony, folklore and traditional belief system(s).

- British period with colonial growth

- Modern form of hegemony

\section{Findings:}

\section{The historical period of concealed hegemony, folklore and traditional belief system(s)}

The wetland Merbeel started to gain importance in different historical texts since the 17 th century A.D. No other historical tracks are found about the wetland and its island that belong to an earlier period than the 17th Century. Folklore about the origin of the wetland and its island is famous in the region. That folklore is directly interlinked with Shri Ram Ata, the first and the most influential NeoVaishnavite leader who successfully led Neo-
Vaishnavite movement ${ }^{2}$ in this region during 17th Century (Mahanta, 1965). NeoVaishnavism was a socio-religious movement in the 15th Century propagated by the social reformer and spiritual master- Srimanta Sankardev to form an egalitarian society without sectarian divisions under the aegis of the spiritual dictum- ek sarana naam dharma. The idea was to simplify and democratise spiritual practice from the erstwhile ritualistic patterns of institutionalised religiosity to selfeffacingly utter various names of God to attain salvation. This form of democratisation of religious patterns was aimed to create a common platform - the naamghars - as a site of socio-cultural and sectarian confluence to form syncretic assimilation (Sahariah et al., 2013; Sarma, 2016; Sharma and Singh, 2016).

Sri Ram Ata established the Shri Shri Bareghar Chaliha Namghar, a famous place of worship of the Vaisnavas of Assam in an adjacent area of the wetland. A critical analysis of the folklore perceivably reveals that it has been symbolically upholding the superiority of the Vaishnavite leaders and thus has created a cultural consensus towards a concealed hegemony intertwined with the religion. The folklore, as recounted by a key respondent was:

Wife of Shri Ram Ata had accidentally once pronounced that she would dedicate her daughter Diti to Merbeel. After that, when Diti attained puberty, Ata dreamt that JalKowar ${ }^{3}$ had been asking for marriage with her. Terrified by the dream, Ata decided to leave their former homeland and shifted to this area, where presently the Merbeel wetland is located. Being annoyed with such attitude of Ata, JalKowar sprouted out furious water channels around Ata's new home and entwined it with a massive wetland of oxbow shape, which was later named

\footnotetext{
${ }^{2}$ Neo-Vaishnavite movement was a socio-cultura revolution of Assam. Sankardev initiated this socio-cultural renaissance in Assam in the late $15^{\text {th }}$ Century
}

${ }^{3}$ JalKowar is a deity. Traditionally it is believed that this deity lives in water. 
as Merbeel. The occurrence of such dreadful incident had made other Bhakat ${ }^{4}$ very frightful, and they convinced Ata to dedicate Diti to the JalKowar and be excused of his anger for violation of promise which may wreak havoc in the future. Accordingly, a majestic arrangement had been made for the marriage and surroundings of the wetland were cleared for marriage ceremony. On that precious day, Bhakat started to pray the JalKowar, and after a long prayer, the JalKowar appeared in a giant boat, made of gold. Only few Bhakat and Ata could see him by their pure heart. Then Diti was sent to that boat and slowly it got submerged in the wetland.

In some specific parts of the folklore, the holiness and divine powers of Shri Ram Ata and Bhakat were represented quite articulately. A part of the folklore states that only few Bhakat and Ata could see the deity by their pure heart. It brought the 'concept of purity' in the psychological atlas of indigenous people and assisted towards the conception of religious hegemony in the name of pure heart.Thisfolklore also provided credence towards the traditional belief of having divine powers in Shri Ram Ata. A divine connection of Shri Ram Ata's family was also established through penetration of the belief that JalKowar got married to Diti, daughter of Shri Ram Ata.

In the traditional society of the region, this folklore formed a complicated nexus of religious hegemony and social hierarchy, with different forms of myths and traditional belief system. Though the Merbeel wetland and its island was a common property resource until the arrival of British in the region, yet natural resources available there remained disproportionately accessed and distributed perceivably due to the intricate manipulative effects of this folklore on the common masses. Myths or rather perceptions were framed that the wetland is a permanent abode of the
JalKowar which was systematically channelised to be an intrinsic part of the traditional belief system. Different rituals were also formed as an upshot of this enforcement process. The main rituals were:

- Whenever some family member fell ill, the villagers used to offer milk to Merbeel in the name of JalKowar. They believed that by the divine power of JalKowar their illness could be wiped out.

- Before starting different village functions, areca nut and a bundle of rice flour were offered to the JalKowar. Villagers used to believe that blessings of JalKowar were vital for the success of any function in the area. This ritual is still in practice in the region.

- Though villagers were dependent on the wetland for different resources, used in their day to day lives, yet they used to believe that the amount of resource extraction should be limited and it should not be haphazard. Otherwise, JalKowar would get angry.

The conservational essence inbuilt in these rituals and the resultant cultural enforcement for the protection of nature was exemplary. Indeed, from the perspective of political ecology, all these rituals had indirectly put a 'common sense' among the villagers regarding the good or bad in the resource extraction process. Though they were not legally bound to anybody or to any institution to follow any rules and regulations in using resources of the wetland and its island, yet a mental ground of rationales regarding 'what to do' or 'what not to do' were persistently playing in their mind, with a profound religious connotation. Eventually, these rituals transformed systematically into social values, rather than compulsions. In this scenario, religiosity rather than religion perse had then become a decisive parameter to both decide and regulate the actions of the villagers vis-à-vis the wetland. Religiosity emanating out of the perceived adherence and allegiance to the JalKowar had given a unique dimension to the

\footnotetext{
${ }^{4}$ Monks of Vaishnavite tradition
} 
physical actions of the villagers in the resource extraction process in and around the wetland. A systematic psychosocial internalisation of the divinity of socially dominant class was another upshot of this folklore. The Vaishnavite leaders were in the apex of the social system in that period, and all these cultural ingredients, either the folklore or the rituals were indirectly outlining more substantial consent among the masses about the divinity of this religious group and soundness of their hierarchical set of social values.

An important ritual that was practised in that period is very noteworthy. In those days, whenever villagers used to catch big fish or turtle in Merbeel, firstly, they used to offer the catch to Bhakat. It was a socio-cultural norm to respect the superior position and divine qualities of Bhakat. Thus, like the extraction process, in the consumption process of resources, also social hierarchy was putting its imprint. The religious hegemony was articulately bred by creating a consensus of conformity to the normativity of perceived religiosity by a tacit appropriation of the then prevalent religious belief system. It had made people accept this hierarchical system without questioning and with their consent, understanding all the socio-cultural manifestations of the system as a means to achieve the good.

\section{British period with colonial growth}

Knowledge was what colonialism was all about - Nicholas Dirks (Dirks, 2001, pp.9)

It remains well documented that although undivided Goalpara district was annexed by the British on 12 August 1765, however, in actuality, Assam became a British protectorate since 1826 following the Treaty of Yandaboo signed between the British and the Burmese King of Ava, to put an end to the First AngloBurmese War (5 March 1824 - 24 February 1826) who had conquered Assam-the kingdoms of Ahom, Cachar, Jayantia hills and Imphal Valley in 1816, 1817 and 1821 (Barpujari, 1992; Bhattacharyya, 2019). The advent of the British Raj brought an entirely new wave of natural resource management in different traditional societies of the world, along with so-called 'scientific' propagation of knowledge. During the colonial period, various forms of civil-society institutions were created by the British, which were the bulwark of their new form of hegemony over the colonised countries (Myers 1998). In the process of colonisation, the dominant group used to enjoy 'spontaneous consent' of the weak group of the third world due to their leading position and function in the production process and as the chief of intellectual and moral leadership (Myers 1998). During British colonialism in India, they brought the idea of scientific forestry with an explanation that the local economy was based on unscientific exploitation of the forest and therefore, local peoples' hold and right over the forests should be restricted to the minimum (Ansari, 2009).

In case of Assam, first, the British only concentrated on lower Assam for forest resource extraction. However, in the second half of the 19th Century, they also started to focus on the natural resources of Upper Assam (Handique, 2004). Particularly, the advent of oil and tea had attracted the British government and accordingly, they started monopolisation in the resource extraction process in the name of conservational policies and practices. In Naharkatiya, situated only 13 kilometres away from Merbeel, extensive tracts of trees were cut and cleared for manufacturing of packaging boxes for tea export and with an objective of construction of railway tracts (Handique 2004). At the same time, the role of the island of Merbeel wetland was transformed from 'resourceful' common rural property to mere rural 'grazing land'. British declared the Merbeel island as 'grazing land' and imposed 'grazing tax' there. That had completely delimited the scope of resource accessibility of indigenous people. For using Merbeel island, indigenous people were compelled to pay grazing tax, which directly provided the colonial government with a scope to collect sufficient taxes. Participant 2, an elderly person from the DhundaNahar village and a witness of the British period recounted: 
During the British period, the British government imposed grazing taxes on the Merbeelisland. Villagers used to pay grazing tax for grazing of buffaloes. Villagers were also bound to pay fine if they were found out to cut tree. All these initiatives were under new forest conservation policy brought by British. However, British themselves used the Merbeel island and Merbeel wetland as a place of recreation. Whenever they wanted, they used to come to the Merbeelisland for hunting. They used to hunt different birds and animals. Usually, they used to hunt water buffaloes which were abundant on the island. Villagers were not allowed to bring timber from the island. The wetland got converted to a scenic property for the villagers rather than a common property resource. (Participant 2, personal communication, 10 August 2018)

This imposition of grazing policy was directly a break in the traditional cycle of hegemony, as with newly formed restrictions, traditional processes associated with wetland resource extraction got weaker. Thereby, the allegiance of the locals towards the Vaishnavite leaders gradually eroded which was manifested in the decline of tradition like offering the first catch during fishing to Bhakat. The legislative policy drew much attention of the locals with a subtle balance of consensus generation and coercion which took supremacy over the erstwhile customary directives and ritualistic practices. British were both protective and very sensitive about their responsibility to protect the valuable and commercially viable forest resources from being exploited by local masses. With the shift in the apex of power dynamics, the allegiance of the common masses had also transgressed the earlier uncrossed mental frontiers of religiosity to the administrative system of access to resources.

\footnotetext{
5 It is an Act of Parliament passed in 2005 as a social security measure for rural population to ensure "Right to
}

Since access to the common resources is the epicentre of the entire argument, the access gets routed through the power centre that channelises the access to the resources by the appropriation of ownership by creating a consensus of the masses to endorse the ownership claim and, if needed, supported by coercive means. The formulaic presupposition may be verified both in the case of Vaishnavite leadership and the British. In the case of British, administrative prudence seemed way too complex for the villagers to understand the taxation dynamics, let alone the aspect of questioning the process, and was augmented by already prevalent hard-handed British military control over the region.

\section{Modern Form of Hegemony}

With the independence of the country in 1947, the Merbeel wetland and its island also got independence from the colonial grazing policy. However, in 2010 during a public meeting to get some grazing land freed from encroachment, a proposal had been passed to convert Merbeel wetland and its island into an ecotourism spot (Indian Express, 2010). The decision was firstly opposed by many villagers, as they were sceptic about its result. However, after a prolonged series of clashes with encroachers, district administration and some influential people of the region were successful in convincing indigenous people about the potential benefits of establishing an ecotourism park. Accordingly, a committee named as 'SasoniMerbeelSanrakshan Committee' was formed with the supreme authority to maintain the ecotourism project. This committee organised public meetings to raise villagers concern about conservation of Merbeel. Oil India Limited joined the venture by coming forward to become an active economic partner. Entire perceivable purpose of this project was included under social forestry, where financial cost was decided to be made, wherever possible, from different schemes of 'Mahatma Gandhi National Rural Employment Guarantee Act' (MGNREGA)..$^{5}$ n

work." As per Comptroller and Auditor General of India report of 2012, MGNREGA was initiated with the objective 
Table 1, various works implemented under MGNREGA to date for the development of the ecotourism park are shown.

\begin{tabular}{|c|c|c|}
\hline Work Name & Financial Year & $\begin{array}{l}\text { Total Cash Payment } \\
\text { (In Rupees) }\end{array}$ \\
\hline $\begin{array}{l}\text { Fishery At MerbilMajuli near Merbil } \\
\text { Ecotourism Project (PH 1) }\end{array}$ & 2017-2018 & 24565 \\
\hline $\begin{array}{l}\text { Public Vermicompost shed at Merbil Eco- } \\
\text { Tourism }\end{array}$ & 2017-2018 & 6783.5 \\
\hline Floriculture At Merbil Eco Tourism & 2017-2018 & 65920 \\
\hline $\begin{array}{l}\text { Raised Platform near Tourism Project } \\
\text { Road }\end{array}$ & 2016-2017 & 91360 \\
\hline $\begin{array}{l}\text { The fishery at MerbilMajuli near Merbil } \\
\text { Ecotourism Project (PH1) }\end{array}$ & 2016-2017 & 24565 \\
\hline $\begin{array}{l}\text { Horticulture Garden At Merbil Eco- } \\
\text { Tourism Compound }\end{array}$ & 2016-2017 & 40000 \\
\hline $\begin{array}{l}\text { Land Development At Eco Tourism Picnic } \\
\text { Place Merbil }\end{array}$ & 2016-2017 & 112680 \\
\hline $\begin{array}{l}\text { Chour Renovation at Merbil (Near Eco- } \\
\text { Tourism Project) }\end{array}$ & 2015-2016 & 25640 \\
\hline $\begin{array}{l}\text { Field Band at Merbil Grazing with Sluice } \\
\text { Gate }\end{array}$ & 2016-2017 & 36225 \\
\hline
\end{tabular}

Source: Collected from Merbil Eco Park during the Field Visit

Local people were guaranteed of employment opportunities under varied work schemes of this project. However, as often: 'all that glitters is not gold'. Again local people of the region have submitted their traditional rights to use natural resources of Merbeel for the development of the project. Though the villagers were ensured to provide limited right to access important resources, yet curtailment of traditional rights was inevitable with growing monopolisation of a single committee in the name of conservational rules and regulations. Local boats of villagers used for fishing purposes were ceased by the district authority. Collection of fodder and fuelwood is brought under the supervision of the committee. With the construction of cottages (Figure 3 ) and horticulture gardening (Figure 4 ), the overall natural setting of the island has transformed to a large extent. Fishing in the wetland is also prohibited now. In case of implementation of different MGNREGA schemes, the gram panchayat plays the role of organiser. It organises unskilled labourers from villages. However, the right of supervision of these works is again enjoyed by the committee. of "enhancing livelihood security in rural areas by providing at least 100 days of guaranteed wage employment in a financial year, to every household whose adult members volunteer to do unskilled manual work." (Bhattacharyya and Vauquline, 2013; Bhattacharyya, 2016) 


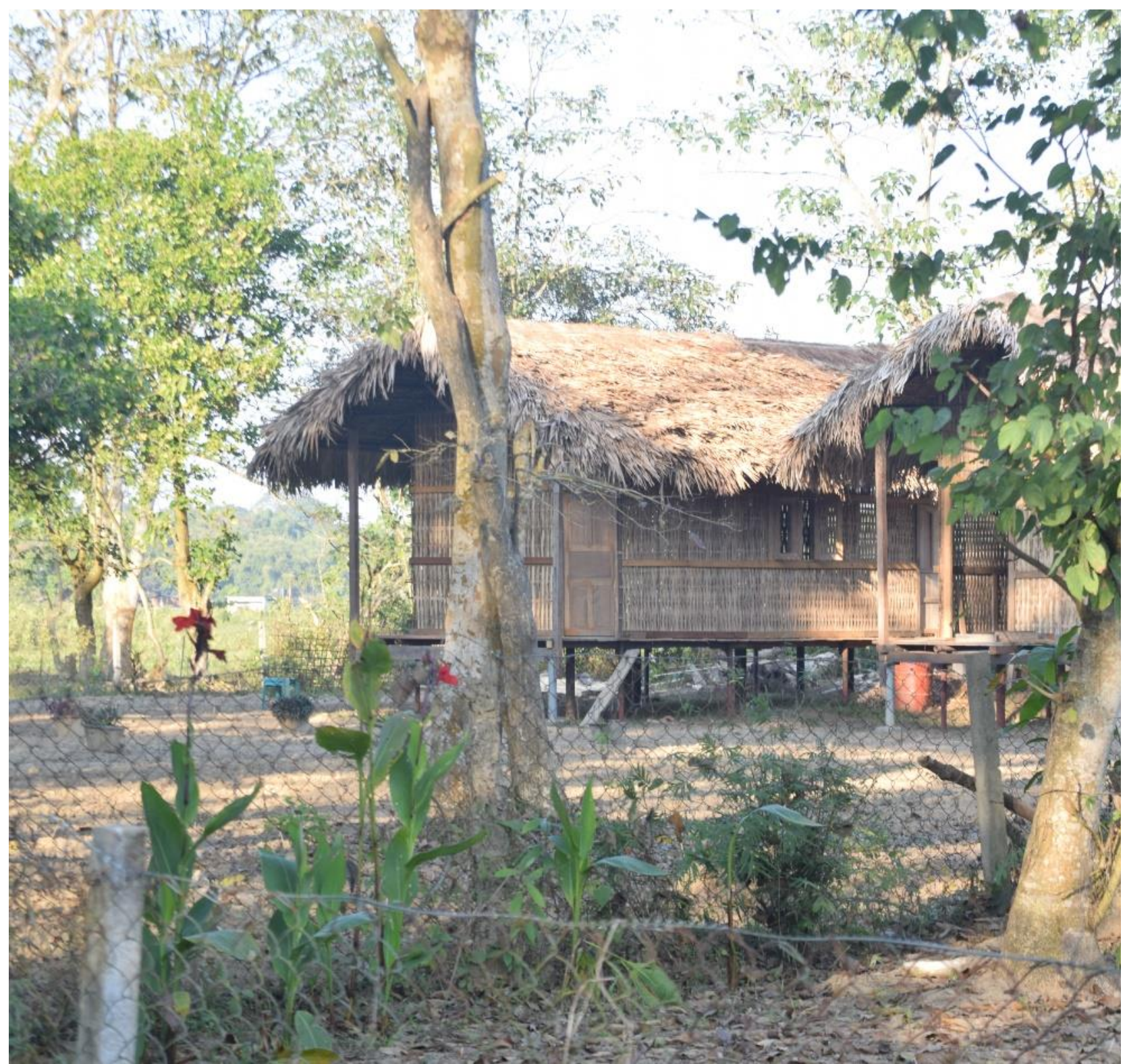

Figure 3: Cottages Constructed in Merbil Eco Park Source: Authors 


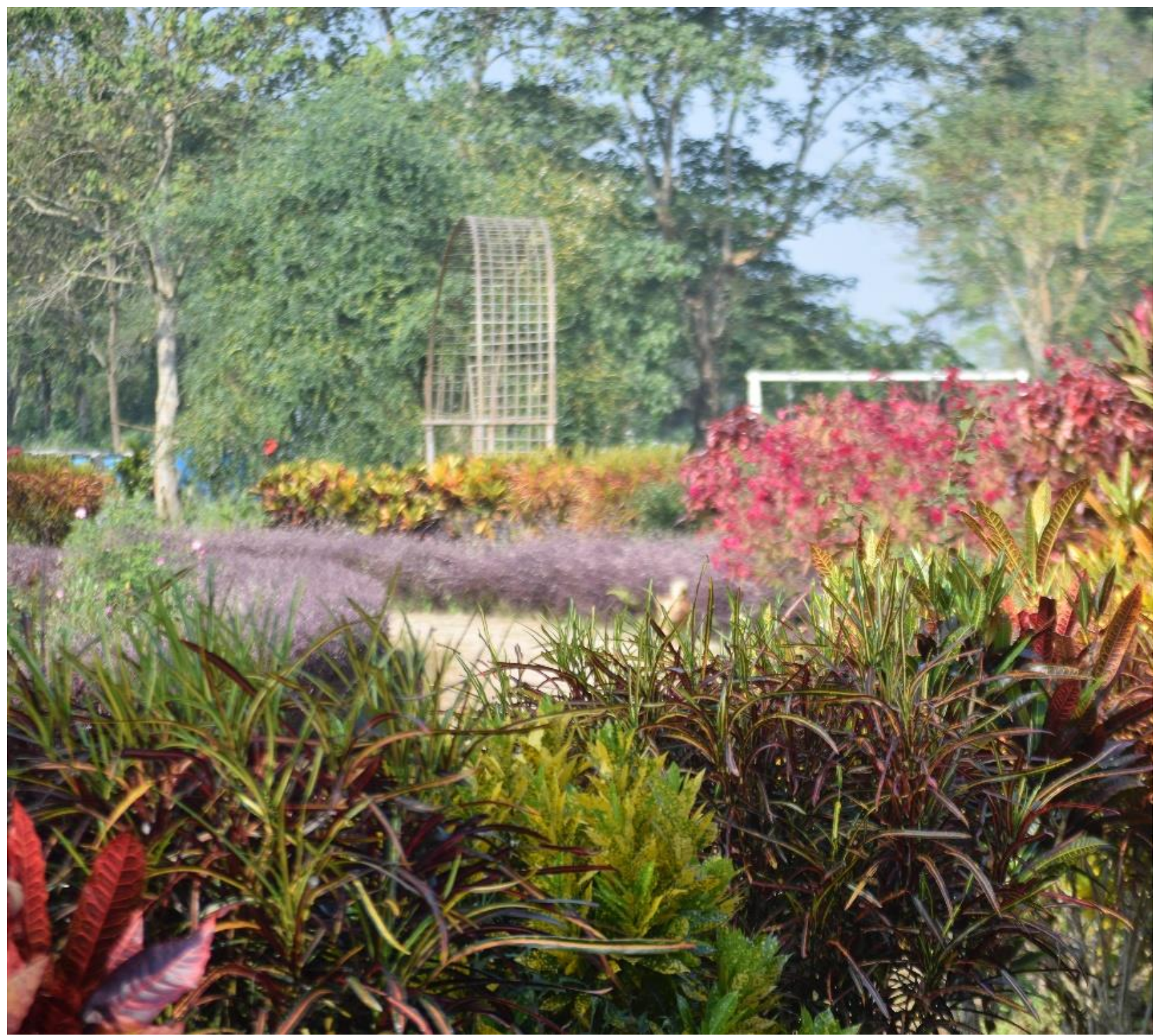

Figure 4: Garden of Merbil Eco Park Source: Authors

\section{Discussion and Conclusion}

In the course of the study, it is noticed that power equation and associated sociohierarchical dynamics gets manifested in varying patterns ranging from pre-colonial times to the current period. Since the wetland and its island are perceivably resourceful so, accessibility to the resources remains a matter of contention. The equation of accessibility and more importantly to maintain exclusive access to resources in the wetland plays the pivotal role in power dynamics associated in and around the wetland. The study also traces a tendency on the part of different groups, trying to assert their socio-cultural, socio-religious and socio-political intention, to legitimise the power equation by various 'discourses' (Foucault, 2001). Reorientation of historiographic processes to assert the subjective 'episteme' about the wetland and its island as 'truth' in the core of these power plays, which is evidently palpable yet surreptitious attempt to mask different group's discerning discourses about the wetland.

Often in the third world countries, state induced natural resource management programmes lead to both monopolisation of power and marginalisation of indigenous people. A similar trend of monopolisation of power is seen as part of this study, wherein past, access to natural resources was articulated by perceivably arbitrary socio-cultural, and religious parameters. In past, religious dictum related to 
the narrative around JalKowar imparts a certain sense of supremacy to a particular group to legitimise the power dynamics in their favour. Religiosity had played itself the information of a pyramid of hierarchy which accommodated the privileges ascertained by the dominant religious group at the cost of marginalisation of the 'other' beyond the epicentre of socio-religious influence. Later, during the British era, under the garb of forest protection, the colonisers again asserted their supremacy in resource accessibility in the name of the scientific method of protection and sustainable use.

In recent periods, the identity of Merbeel wetland and its island has been transforming from a common property resource to an aesthetic resource. Local people have already lost certain traditional rights to enjoy the natural resources of Merbeel freely. The decision making power is now fully in the hand of the committee, which is a new addition of hegemonic progression. Such situation could be harmful to a rural society, which has a significant social, cultural and economic interrelationship with its environment or particularly with common property resource, as it indirectly leads to disguised privatisation of a public resource in the name of development. So, it may be deduced from certain observations that the wetland and its resources have perceivably been under a through hegemonic control of one group or the other in shifting contours of power dynamics from time to time. The question of whether exclusive access to the resources of the wetland is good or bad for the region is beyond the scope of the study, but the study has recorded substantial evidence which claims that exclusivity inaccessibility is crucial to analyse the political ecology entwined with social powers and local environments.

\section{References}

Alkire, S., Foster, J. E., Seth, S., Santos, M. E., Roche, J. M., and Ballon, P.

(2015).Multidimensional Poverty Measurement and Analysis, Oxford: Oxford University Press, Chapter 2. Retrieved on 05 February 2015 http://www.ophi.org.uk/wpcontent/uploads/OPHIWP083_Ch2.pdf
Allen, J. (2003). Lost Geographies of Power. RGS-IBG Book Series: Blackwell Publishing Althusser, L. (1971). Lenin and Philosophy and Other Essays (pp. 127-188). London: NLB.

Ansari, M. (2009). Politics of Conservation (Dissertation submitted to the University of Delhi in partial fulfilment of the requirement for the award of the degree of Master of Philosophy). University of Delhi.

Barpujari, H. (1992). The Comprehensive History of Assam. Guwahati: Publication Board Assam.

Bhattacharyya, D. (2016). Drawing a LinkWomen's Empowerment and Mahatma Gandhi National Rural Employment Guarantee Act: A Study Conducted in the Goalpara District, Assam. Space and Culture, India, 3(3), 21. doi: 10.20896/saci.v3i3.180

Bhattacharyya, R. (2017). India Rising. Space and Culture, India, 5(1), 1. Doi:

10.20896/saci.v5i1.258

Bhattacharyya, R., \&Pulla, V. (2019). Prime Minister Modi Returns, 2019: New Governance Agenda. Space and Culture, India, 7(1), 1-14. Doi: $10.20896 /$ saci.v7i1.569

Bhattacharyya, R., \& Vauquline, P. (2013). A Mirage or a Rural Life Line? Analysing the impact of Mahatma Gandhi Rural Employment Guarantee Act on Women Beneficiaries of Assam. Space and Culture, India, 1(1), 83. doi: 10.20896/saci.v1i1.10

Bryant, R. (1997). Beyond the impasse: the power of political ecology in Third World environmental research. Area, 29(1), 5-19. doi: 10.1111/j.1475-4762.1997.tb00003.x

Bryant, R., \& Bailey, S. (1997). Third World Political Ecology. London: Routledge.

Coria, J., \& Calfucura, E. (2012). Ecotourism and the Development of Indigenous Communities: The Good, the Bad, and the Ugly. Ecological Economics, 73, 47-55. doi: 10.1016/j.ecolecon.2011.10.024

Dirks, N. (2001). Castes of Mind: Colonialism and the Making of Modern India (1st ed., p. 9). New Jersey: Princeton University Press. 
Dyson, J. (2008). Harvesting Identities: Youth, Work, and Gender in the Indian Himalayas. Annals of the Association of American Geographers, 98(1), 160-179. doi: $10.1080 / 00045600701734554$

Dyson, J. (2014). Working Childhoods. Cambridge: Cambridge University Press.

Foucault, M. (2001). Truth and Power. In V. Leitch, The Notion Anthology of Theory and Criticism (pp. 1667-1670). New York: W.W.Norton.

Giri, S. (2003). Sifting Through The Ecology Debate: Labour and the Production of Nature (Ph.D Thesis). Jawaharlal Nehru University.

Gramsci, A., Hoare, Q., \& Nowell-Smith, G. (2008). Selections from the Prison Notebooks of Antonio Gramsci. New York: International Publishers.

Hancock, B., Ockleford, E., \& Windridge, K. (2007). An Introduction to Qualitative Research [Ebook]. The NIHR RDS EM/YH. Retrieved on 10 January 2018 from, http://www.rdsyh.nihr.ac.uk

Handique, R. (2004). British Forest Policy in Assam. New Delhi: Concept Publ.

Haviland, W., Prins, H., McBride, B., \& Walrath, D. (2008). Cultural Anthropology the Human Challenge (13th ed.). Belmont: Wadsworth Cengage Learning.

Jewitt, S. (2008). Political Ecology of Jharkhand Conflicts. Asia Pacific Viewpoint, 49(1), 68-82. doi: 10.1111/j.1467-8373.2008.00361.x

Karlsson, B. (2015). Political Ecology: Anthropological Perspectives. In J. Wright, International Encyclopedia of the Social \& Behavioral Sciences (2nd ed., pp. 350-355). Oxford: Elsevier.

Kashyap, S. (2010). Discovering Sasoni. Indian Express. Retrieved on 10 January 2018 from, http://archive.indianexpress.com

Khan, M. (2013). Theoretical Frameworks in Political Ecology and Participatory Nature/Forest Conservation: The Necessity for a Heterodox Approach and the Critical Moment.
Journal of Political Ecology, 20(1), 460. doi: 10.2458/v20i1.21757

Leff, E. (2015). Political Ecology: a Latin American Perspective. Desenvolvimento E Meio Ambiente, 35, 29-64. doi:

10.5380/dma.v35i0.44381

Mahanta, M. (1965). Shri Shri Ramdeb Charitra (pp. 132-133). Sibsagar: Mihir Chandra Mahanta.

Mann, G. (2009). Should political ecology be Marxist? A case for Gramsci's historical materialism. Geoforum, 40(3), 335-344. doi: 10.1016/j.geoforum.2008.12.004

Myers, G. (1998). Intellectual of Empire: Eric Dutton and Hegemony in British Africa. Annals of The Association Of American Geographers, 88(1), 1-27. doi: 10.1111/1467-8306.00082 Omonijo, D., Uche, O., Nnedum, O., \& Chine, B. (2016). Religion as the Opium of the Masses: $A$ Study of the Contemporary Relevance of Karl Marx. Asian Research Journal of Arts \& Social Sciences, 1(3), 1-7. doi: 10.9734/arjass/2016/28326

Pulla, V. (2017). Gramscian 'Counter hegemony' in Narendra Modi's New India Perspective.

Space and Culture, India, 4(3), 1-6. Doi:

10.20896/saci.v4i3.247

Sahariah, D., Singha, K., Bora, D., Kundu, S., Das, T., \& Sen, S. et al. (2013). Majuli at the Crossroads: A Study of Cultural Geomorphology. Space and Culture, India, 1(2), 12-20. doi: 10.20896/saci.v1i2.26

Sarma, D. (2016). Reading Syed Abdul Malik's Dhanya Nara Tanu Bhal and Rudrani Sarma's Lauhitya Tirar Amrit Gatha in the light of Assamese Vaishnavite Hagiography. Space and Culture, India, 4(2), 39-44. doi: 10.20896/saci.v4i2.222

Sharma, P., \& Singh, A. (2016). Changing Notions of "Ideal" Monkhood: A Case Study from a Satra of Majuli. Space and Culture, India, 4(2), 29-38. doi: 10.20896/saci.v4i2.199

Sharma, R., McGREGOR, M., \& Blyth, J. (1991). The Socio-Economic Evaluation of Social Forestry in Orissa, India. International Tree 
Crops Journal, 7(1-2), 41-56. doi: 10.1080/01435698.1991.9752901

Singh, S. (2014). Women, Environment and Sustainable Development: A Case Study of Khul Gad Micro Watershed of Kumoun Himalaya. Space and Culture, India, 1(3), 53-64. doi: 10.20896/saci.v1i3.45

Singh, S. B. (2015). Women as Milieu Managers in Integrated Watershed Management:

Perspectives from the Hilly Areas of Uttarakhand. Space and Culture, India, 2(4), 7179. https://doi.org/10.20896/saci.v2i4.130

Stoddart, M. (2007). Ideology, Hegemony, Discourse: A Critical Review of Theories of Knowledge and Power. Social Thought and Research, 191-225. doi: 10.17161/str.1808.5226

Svarstad, H., Benjaminsen, T., \&Overå, R. (2018). Power theories in political ecology. Journal of Political Ecology, 25(1), 351-363. Doi: 10.2458/v25i1.23044
The Paris Agreement, United Nations Climate Change. Retrieved on 09 January 2020 from, https://unfccc.int/process-and-meetings/theparis-agreement/the-paris-agreement

Young, I. (2004). Modest Reflections on Hegemony and Global Democracy. Theoria, 51(103), 1-14. doi:

$10.3167 / 004058104782267277$

\section{Acknowledgements}

This work is supported by the Indian Council of Social Science Research (ICSSR) under Centrally Administered Doctoral Fellowship, RFD/201718/GEN/GEOG/270.We acknowledge the financial support provided by the Indian Council of Social Science Research (ICSSR), New Delhi in the successful completion of this study. We acknowledge the valuable comments of the anonymous reviewers. Lastly, we also acknowledge the constant guidance of Dr Pranjal Protim Barua, Assistant Professor of Department of English, Motilal Nehru College, New Delhi, for his help in executing the manuscript. 